Amino acid analysis was performed in an automatic amino acid analyser (KLA-3B type, Hitachi Ltd.) by the method of Spackman et al. (3).

As shown in Table 1, denatured casein and bovine hemoglobin, trypsin- and chymotrypsin-type substrates such as substrate No. 7-11, were not hydrolysed to any appreciable extent. Moreover, we found previously (2), that ovomucoid trypsin inhibitor and TPCK (N-tosylphenylalanine chloromethylketone, a specific chymotrypsin inhibitor) had no effect on the enzyme activity. These facts suggest that the enzyme has not proteinase activity like trypsin and chymotrypsin. In the present experiment, hippuryl-L-lysine was not hydrolysed. Zinc and cobalt ions and EDTA also inhibited the enzyme activity. These results imply that our enzyme preparation differs from the carboxypeptidase B and carboxypeptidase $N(4,5)$. The analysis of amino acid composition of partially purified enzyme showed that the preparation contained much amount of aspartic acid $(12 \%)$ and glutamic acid $(14 \%)$ but littlc cystine $(2 \%)$. Glutathione and cysteine inhibited our cnzyme preparation and its activity was increased by SH-reagents (2). These observations suggest that the $\mathrm{SH}$-residue plays an important role in the mechanis m of the enzyme action.

To obtain an ultracentrifugally and electrophoretically homogeneous preparation, further purification are now in progress.

\title{
REFERENCES
}

1) Iwata, H., Shikimi, T. and Oka, T.: Biochem. Pharmac. 18, 119 (1969); 2) Shikimi, T. and Iwata, H.: Biochem. Pharmac. 19, (1970) in press ; 3) Spackman, D.H., Stein, W.H. and Moore, S.: Analyt. Chem. 30, $1190(1958)$; 4) Erdös, E.G. ANd Sloane, E.M.: Biochem. Pharmac. 11, 585 (1962); 5) Yang, H.Y.T. and Erdös, E.G.: Nature, Lond. 215, 1402 (1967); 6) Goldbarg, J.A. and Rutenburg, A.M.: Cancer 11, 283 (1958); 7) Yamamura, Y. AND ODA, T.: Enzymes and Diseases, p. 411, Igaku Shoin, Tokyo (1965); 8) Folk, J.E., Piez, K.A., Carroll, W.R. and Gladner, J.A.: J. biol. Chem. 235, 2272 (1960); 9) Hatano, H. and Kirita, T.: Kagaku no Ryoiki suppl. 34, p. 46, Nankodo Co. Ltd., Tokyo (1958); 10) Hummel, B.C. : Can. J. Biochem. Physiol. 37, 1393 (1393); 11) Martin, G.J., Golubow, J. AND Axelrod, A.E. : J. biol. Chem. 234, 294 (1959) ; 12) Bundy, H.F. : Anal. Biochem. 3, 431 (1962) ; 13) Schwert, G.W. ANd Takenaka, Y.: Biochem. biophys. Acta 16, 570 (1955) ; 14) Bergmeyer, H.U.: Methods of Enzymatic Analysis, p. 815, Academic Press, New York (1963); 15) BERgmeYER, H.U. : Ibid. p. 811 (1962) ; 16) Hagrwara, B. : Kosokenkyuho II p. 242, Ed. Akabori, S. Asakura Shoten, Tokyo (1961).

\section{INFLUENCE OF METHYLAMPHETAMINE ON BLOOD LACTIC ACID FOLLOWING EXERCISE}

\author{
A.K. CHATTERJEE, S.A. JAGOB, R.K. SRIVASTAVA, \\ P.R. PABRAI AND A. GHOSE \\ Jiwaji Resenrch Laborator', Dell. Defence Research Laboratory, Gwalior-2, India \\ Received for publication November 10, 1969
}

It has been shown by Weiss and Laties ${ }^{1)}$ that amphetamines, besides being central stimulants, not only improve physical performance but also a motivation to perform the work better, and more so when fatigue is setting in. Prolonged exercise with the concomitant relative muscular anoxia causes accumulation of lactic acid in blood and tissues because its uptake by liver is slower than its rate of production by the muscle. Since amphetamines delayed fatigue, it looked desirable to study the effect of methylamphetamine on the 
level of lactic acid in blood after regulated but prolonged exercise.

Male albino rats, weighing between 200 to $250 \mathrm{~g}$, were divided into seven groups of 7 or more animals each. Animals were exercised on a treadmill moving at a speed of 1.25 miles per hour for a period of 30 minutes. Animals were put in a holder so that their front legs only were made to work. Division of animals and the treatment given to them are shown below:

Group I -without drug and without exercise

Group II - without drug but with exercise

Group III -injected with $0.3 \mathrm{mg} / \mathrm{kg}$ drug followed by exercise for 50 minutes

Group IV -injected with $1.0 \mathrm{mg} / \mathrm{kg}$ drug followed by exercise for 50 minutes

Group V ---injected with $2.0 \mathrm{mg} / \mathrm{kg}$ drug followed by exercise for 50 minutes

Group VI -injected with $3.0 \mathrm{mg} / \mathrm{kg}$ drug followed by exercise for 50 minutes

Group VII -injected with $5.0 \mathrm{mg} / \mathrm{kg}$ drug followed by exercise for 50 minutes

Methylamphetamine hydrochloride was given intraperitoneally half an hour prior to exercise. Immediately on termination of the exercise, animals were anaesthetized with ether and blood was taken by a cardiac puncture and put into a bottle containing sodium fluoride. This series of operations from termination of exercise to collection of blood by cardiac puncture took approximately 5 minutes. Blood lactic acid was determined according to method of Barker and Summerson (2). Results obtained, after statistical analysis, are presented in Table 1 and show that:

TABLE 1. Effect of methylamphetamine on blood lactic acid levels in rats.

\begin{tabular}{ccccc}
\hline Group No. & Exercise* & $\begin{array}{c}\text { Dose } \\
\mathrm{mg} / \mathrm{kg}\end{array}$ & $\begin{array}{c}\text { No. of } \\
\text { animals }\end{array}$ & $\begin{array}{c}\text { Blood lactic acid }(\mathrm{mg} \%) \\
\text { Mean } \pm \text { S.D. }\end{array}$ \\
\hline I & - & nil & 8 & $20.1 \pm 1.8$ \\
II & - & nil & 8 & $36.3 \pm 13.2$ \\
II & - & 0.3 & 11 & $33.5 \pm 8.5$ \\
IV & - & 1.0 & 8 & $15.6 \pm 6.6$ \\
V & - & 2.0 & 11 & $17.8 \pm 5.0$ \\
VI & - & 3.0 & 11 & $21.3 \pm 11.7$ \\
II & - & $\mathbf{5 . 0}$ & 7 & $68.4 \pm \mathbf{8 . 5}$ \\
\hline
\end{tabular}

* Exercise means running on treadmill for 50 minutes at the rate of $1.25 \mathrm{miles} /$ hour $;(-)=$ No exercise or resting state $(+)=$ After exercise.

1. Exercise per se increases blood lactic acid significantly $(\mathrm{P}<0.01$ for Group I versus II).

2. Methylamphetamine at $0.3 \mathrm{mg} / \mathrm{kg}$ body weight had no significant effect on blood lactic acid (Group III vesrus II).

3. Blood lactic acid levels in groups IV, V and VI were significantly lower than in group II animals ( $\mathrm{P}<0.01$ for groups IV \& V veruss group II; $\mathrm{P}<0.05$ group VI versus II)

4. Levels of lactic acid in blood after exercise with drug (Groups IV, V, VI) did not differ significantly from that of Group I where neither exercise nor drug was given.

5. While intergroup differences between Groups IV, V and VI were not significant, blood lactic acid concentration after $5.0 \mathrm{mg} / \mathrm{kg}$ body weight of drug (Group VII) was higher than at $3.0 \mathrm{mg} / \mathrm{kg}$ dosage (Group VI), indicating that further increase in drug dosage began to reverse its effect.

Data presented above give sufficient evidence to indicate that methylamphetamine $(1.0 \mathrm{mg}$ to $3.0 \mathrm{mg}$ per $\mathrm{kg}$ body weight) prevented rise in lactic acid concentration of blood following exercise. Respiratory centre is stimulated by amphetamines in laboratory animals and there is an increase in rate and depth of respiration (3). It appears that lactic acid produced by muscular contraction has been better utilized under the effect 
of the drug and kept low by increased oxygen availability. In this connection it is noteworthy that methylamphetamine even at dosage of $10 \mathrm{mg}$ per $\mathrm{kg}$ body weight failed to alter blood lactic acid levels in unexercised mice (4). In the light of observations of Hardinge and Peterson (5) that amphetamine toxicity in mice was increased after exercise, it is likely that $5 \mathrm{mg}$ per $\mathrm{kg}$ dose of methylamphetamine used in our study reached toxic levels. Reversal of certain psychomotor responses with higher doses of methylamphetamine has been recorded by Maffii (6) and Kameyama (7). A similar reversal of effect on lactic acid level has been observed here.

Even though it has not been possible to elucidate the exact machanism by which the drug helped in keeping blood lactic acid concentration low, the study does indicate that optimal doses of methylamphetamine improve physical work efficiency by preventing a rise in blood lactic acid levels after exercise.

\section{REFERENCES}

1) Weiss, B. and Laties, V.G.: Pharmac. Rev. 14, 1 (1962); 2) Barker, S.B. and Summerson, W.H.: J. biol. Chem. 138, 535 (1941); 3) Innes, I.R. ANd Nickerson, M.: Pharmacological Basis of Therapeutics, 3rd Ed., Edited by Goodman, L.S. and Gilman, A., p. 500, MacMillan Co., New York (1965); 4) Moore, K.E.: J. Pharm. Pharmac. 18, 196 (1966); 5) Hardinge, M.G. and Peterson, D.I.: J. Pharmac. exp. Ther. 141, 260 (1963); 6) MAFFII, G.: Farmaco. (Pavia) Ed. Sci. 14, 440 (1959); Chem. Abstr. 54, 9106 (1960); 7) KameYama, T.: Yakugaku Zasshi 81, 215 (1961); Chem. Abstr. 55, 26247 (1961) 